Vol. 1 No. 2 2018, Hal. 69-84

\title{
FENOMENA KOTAK KOSONG DALAM PEMILUKADA SERTA IMPLIKASINYA DALAM SISTEM KETATANEGARAAN INDONESIA
}

\author{
Ahmad Gelora Mahardika \\ Hukum Tata Negara Institut Agama Islam Negeri Tulungagung \\ Jl. Major Sujadi Timur No. 46, Tulungagung \\ geloradika@gmail.com
}

\begin{abstract}
The decision of Indonesian Constitutional Court No. 100/PUU-XII/2015 legitimizing single candidate give solution for democracy deadlock in some regions.Based on that decision, The Election Commission make a regulation giving alternative for some regions having only one candidate for choosing the picture of candidate against empty box. These battle in the beginning seems not fair because of political intention, empty box has no resources to compete with candidate. But, in the local election 2018, in some regions, empty box success to gain more voters than his rival. Winning of empty box in contestation of democracy became a proof that people feel tired because the system of regeneration in political parties not running well, other proof that single candidate that bring up by all political parties not always supported by voters. In the Indonesia constitutional law, the phenomenon of empty box surely implicate tomany problems. This writing will try to see this phenomenon and its implication according to Indonesian constitutional law.
\end{abstract}

Key words: Democracy, Empty box, Political parties, Local Election

Putusan Mahkamah Konstitusi Nomor100/PUU-XIII/2015 yang mengesahkan calon tunggal secara plebisit memberi solusi atas kebuntuan demokrasi yang saat itu terjadi di sejumlah daerah. Berdasarkan Putusan tersebut, KPU kemudian membuat Peraturan 
KPU yang memberikan alternatif bagi daerah yang hanya terdapat satu orang calon untuk memilih gambar calon dihadapkan melawan kotak kosong. Pertarungan itu pada awalnya terkesan tidak seimbang karena secara nalar politik, kotak kosong bukan calon yang mempunyaisumberdayapolitik untukbersaing. Akan tetapi padaPemilukada 2018 justru di sejumlah daerah kotak kosong memenangkan kontestasi politik. Kemenangan kotak kosong dalam kontestasi demokrasi selain menjadi bukti kejenuhan masyarakat terhadap tidak berjalannya fungsi kaderisasi partai politik, juga membuktikan pula bahwa calon tunggal yang diusung oleh semua partai politik belum tentu didukung oleh rakyat. Dalam sistem ketatanegaraan Indonesia, fenomena kotak kosong tentu saja berimplikasi terhadap sejumlah persoalan. Tulisan ini akan mencoba melihat fenomena kotak kosong dan implikasinya dalam sistem ketatanegaraan Indonesia.

Kata Kunci: Demokrasi, KotakKosong, PartaiPolitik, Pemilukada

\section{Pendahuluan}

Putusan Mahakamah Konstitusi Nomor 100/PUU-XIII/2015 menjadi solusi atas kebuntuan demokrasi yang terjadi di sejumlah daerah. Para pembuat undangundang (law makers) pada awalnya tidak pernah memperkirakan adany kemungkinan lahirnya calon tunggal dalam kontestasi politik di tingkat lokal. Hal itu disebabkan dengan sistem multi partai serta kencangnya arus demokrasi, kemungkinan lahirnya calon tunggal dianggap nihil. Akan tetapi, sesuatu yang seharusnya (das sollen) tidak akan terjadi bukan tidak mungkin akan terjadi. Pada kenyataannya (das sein), fenomena ini terjadi pada Pilkada tahun 2015, ketika sejumlah daerah seperti Kabupaten Blitar (Jawa Timur), Kabupaten Tasikmalaya (Jawa Barat), Kabupaten Timor Tengah Utara (Nusa Tenggara Timur), Kota Mataram (Nusa Tenggara Barat), dan
Kota Samarinda (Kalimantan Timur) hingga penutupan pendaftaran sampai dibuka kembali perpanjangan oleh KPUD, kandidat yang mendaftar untuk menjadi kepala daerah hanya satu orang (nationaltempo.com, diakses tanggal 23 Agustus 2018).

Persoalan yang muncul adalah Undang-Undang Nomor 8 Tahun 2015 tentang Pemilihan Kepala Daerah ternyata tidak memberikan solusi terkait persoalan tersebut. Hal ini menyebabkan beberapa orang yang mengatasnamakan rakyat yang dirugikan hak konstitusinya kemudian mengajukan gugatan ke Mahkamah Konstitusi untuk menguji konstitutionalitas terkait pasal kewajiban minimal harus adanya dua pasangan calon tersebut. Mahkamah Konstitusi kemudian mengabulkan sebagian permohonan uji materiUndang-Undang Nomor 8 Tahun 2015 yang dimohonkan oleh Akademisi 
Effendi Gazali. Dalam putusan tersebut, Mahkamah Konstitusi menyatakan Pemilihan Kepala Daerah yang hanya diikuti oleh satu pasangan calonkepala daerah dan wakil kepala daerah dapat dilaksanakan apabila telah diusahakan dengan sungguh-sungguh terpenuhinya syarat paling sedikit dua pasangan calon. Untuk itu, Pemilukada tidak lagi sematamata digantungkan pada keharusan paling sedikit adanya dua pasangan calon kepala daerah dan calon wakil kepala daerah (Putusan Mahkamah Konstitusi Nomor 100/PUU-XII/2015).

Menurut Mahkamah, dalam Undang-Undang Pemilukada, tampak bahwa pembentuk Undang-Undang ingin kontestasi Pemilukada setidaknya diikuti dua pasangan calon. Namun, pembentuk Undang-Undang tidak memberikan jalan keluar alternatif apabila syarat setidaknya dua pasangan calon tersebut tidak terpenuhi."Dengan demikian, akan ada kekosongan hukum manakala syarat paling kurang dua pasangan calon tersebut tidak terpenuhi. Kekosongan hukum itu akan berakibat padatidak dapat diselenggarakannya Pemilihan Kepala Daerah. Mahkamah mengimbuhkan, adanya kekosongan hukum tersebut telah mengancam tidak terlaksananya hak-hak rakyat untuk dipilih dan memilih karena dua alasan. Pertama, penundaan ke Pemilihan serentak berikutnya sesungguhnya telah menghilangkan hak rakyat untuk dipilih dan memilih pada Pemilihan serentak saat itu. Kedua, apabila penundaan demikian dapat dibenarkan, tetap tidak ada jaminan bahwa pada Pemilihan serentak berikutnya itu, hak rakyat untuk dipilih dan memilih akan dapat dipenuhi. Pasalnya, penyebab tidak dapat dipenuhinya hak rakyat untuk dipilih dan memilih itu tetap ada, yaitu ketentuan yang mempersyaratkan paling sedikit adanya dua pasangan calon dalam kontestasi Pemilukada, oleh karena itu, menurut Mahkamah, Pemilukada yang ditunda sampai pemilihan berikutnya hanya karena tak terpenuhinya syarat paling sedikit dua pasangan calon bertentangan dengan UUD 1945. "Demi menjamin terpenuhinya hak konstitusional warga negara, pemilihan Kepala Daerah harus tetap dilaksanakan meskipun hanya terdapat satu pasangan calon kepala daerah dan calon wakil kepala daerah, setelah sebelumnya diusahakan dengan sungguh-sungguh untuk mendapatkan paling sedikit dua pasangan calon.

Akan tetapi sebagaimana biasanya, Putusan Mahkamah Konstitusi hanyalah menyatakan bertentangan atau tidak bertentangan dengan konstitusi, karena Putusan MK pada dasarnya tidak menciptakan hukum baru (negative legislator), oleh karena itulah persoalan teknis terkait dengan pelaksanaan Pemilukada dengan calon tunggal diserahkan sepenuhnya pada KPU.

Menindaklanjuti Putusan MK tersebut, kemudian KPU membuat Peraturan Komisi Pemilihan Umum (PKPU) Nomor 14 tahun 2015 tentang Pilkada yang mengatur teknis pemilihan dengan kandidat perseorangan. Sadar bahwa secara kedudukan hukum kurang kuat, pembuat undang-undang kemudian menindaklajuti Putusan tersebut ke dalam Undang-Undang Nomor 10 Tahun 2016 tentang Pemilihan Kepala Daerah (Pilkada) yang berbunyi sebagai berikut: 
Pasal 54C (1)

Pemilihan 1 (satu) pasangan calon dilaksanakan dalam hal memenuhi kondisi:

a) Setelah dilakukan penundaan dan sampai dengan berakhirnya masa perpanjangan pendaftaran, hanya terdapat 1 (satu) pasangan calon yang mendaftar dan berdasarkan hasil penelitian pasangan calon tersebut dinyatakan memenuhi syarat;

b) terdapat lebih dari 1 (satu) pasangan calon yang mendaftar dan berdasarkan hasil penelitian hanya terdapat 1 (satu) pasangan calon yang dinyatakan memenuhi syarat dan setelah dilakukan penundaan sampai dengan berakhirnya masa pembukaan kembali pendaftaran tidak terdapat pasangan calonyang mendaftar atau pasangan calon yang mendaftar berdasarkan hasil penelitian dinyatakan tidak memenuhi syarat yang mengakibatkan hanya terdapat 1 (satu) pasangan calon;

c) Sejak penetapan pasangan calon sampai dengan saat dimulainya masa Kampanye terdapat pasangan calon yang berhalangan tetap, Partai Politik atau Gabungan Partai Politik tidak mengusulkan calon/pasangan calon pengganti atau calon/pasangan calon pengganti yang diusulkan dinyatakan tidak memenuhi syarat yang mengakibatkan hanya terdapat 1 (satu) pasangan calon;

d) Sejak dimulainya masa Kampanye sampai dengan hari pemungutan suara terdapat pasangan calon yang berhalangan tetap, Partai Politik atau Gabungan Partai Politik tidak mengusulkan calon/pasangan calon pengganti atau calon/pasangan calon pengganti yang diusulkan dinyatakan tidak memenuhi syarat yang mengakibatkan hanya terdapat 1 (satu) pasangan calon; atau

e) terdapat pasangan calon yang dikenakan sanksi pembatalan sebagai peserta Pemilihan yang mengakibatkan hanya terdapat 1 (satu) pasangan calon.

Ketentuan itu kemudian diatur secara teknis dalam Peraturan Peraturan KPU Nomor 13 Tahun 2018 Pasal 25 ayat 1 sampai 3 tentang pilkada dengan Satu Pasangan Calon. Pasal 25 tersebut berbunyi;

(1) Apabila perolehan suara pada kolom kosong lebih banyak dari perolehan suara pada kolom foto Pasangan Calon, KPU Provinsi/KIP Aceh atau KPU/KIP Kabupaten/ Kota menetapkan penyelenggaraan Pemilihan kembali pada Pemilihan serentak periode berikutnya.

(2) Pemilihan serentak berikutnya sebagaimana dimaksud pada ayat (1) dapat diselenggarakan pada tahun berikutnya atau dilaksanakan sebagaimana jadwal sesuai dengan ketentuan peraturan perundangundangan.

(3) Dalam hal terjadi penetapan penyelenggaraan Pemilihan serentak periode berikutnya sebagamana dimaksud pada ayat (1), KPU Provinsi/KIP Aceh atau KPU/KIP Kabupaten/Kota melalui KPU berkoordinasi dengan kementerian yang membidangi urusan dalam negeri untuk penugasan penjabat Gubernur dan Wakil Gubernur, 
penjabat Bupati dan Wakil Bupati, atau penjabat Wali Kota dan Wakil Wali Kota

Lepas dari adanya putusan MK terkait keberadaan calon tunggal, fenomena ini muncul dalam kontestasi demokrasi di Indonesia disebabkan oleh gagalnya partai politik dalam menjalankan fungsinya sebagai sarana kaderisasi politik. Kondisi ini tentu saja tidak sehat baik bagi keberlangsungan demokrasi Indonesia maupun bagi sistem ketatanegaraan Indonesia.

Apabila kita mengacu pada Pasal 11 Undang-Undang Nomor 2 Tahun 2008 tentang Partai Politik, Partai Politik mempunyai beberapa fungsi integral yaitu sebagai pendidikan politik, penciptaan iklim yang kondusif bagi persatuan dan kesatuan bangsa Indonesia, aspirasi politik masyarakat, partisipasi politik dan rekrutmen politik dalam proses pengisian jabatan politik melalui mekanisme demokrasi.

Pada fungsi rekrutmen politik inilah, Peran Partai Politik sangat vital dalam sistem ketatanegaraan kita. Partai Politik merupakan satu-satunya kendaraan alternatif bagi kader-kader bangsa untuk menduduki jabatan-jabatan strategis di pemerintahan, hal itu disebabkan hingga hari ini kita belum menemukan sistem alternatif untuk pengisian jabatanjabatan strategis dipemerintahan selain melalui partai politik. Secara otomatis berfungsinya pelembagaan partai politik secara ideal akan berefek positif terhadap penguatan sistem ketatanegaraan dan itu berbanding lurus terhadap peningkatan kualitas kehidupan berdemokrasi, dan begitupula sebaliknya apabila Partai Politik gagal dalam menjalankan fungsinya sebagai sarana rekrutmen politik, maka akan muncul kekhawatiran bahwa sistem ketatanegaraan kita akan terjebak dalam sejumlah persoalan sebagaimana yang terjadi diera orde baru, dan secara tidak langsung akan mengurangi kualitas kehidupan demokrasi kita.

Sebagaimana kita ketahui pada era orde baru, sistem ketatanegaraan Indonesia tidak berjalan sebagaimana mestinya. Secara yuridis, terdapat lembaga tertinggi MPR, namun secara empiris lembaga kekuasaan eksekutif begitu berkuasa baik terhadap lembaga yudikatif maupun legislatif, dan kondisi itutidak sehat bagi iklim demokrasi kita. Berangkat dari kekhawatiran itulah, tulisan ini akan membahas mengenai fenomena calon tunggal di beberapa daerah serta bagaimana implikasinya dalam sistem ketatanegaraan di Indonesia.

\section{Metode Penelitian}

Pelaksanaan penelitian "Fenomena Kotak Kosong Dalam Pemilukada Serta Implikasinya Dalam Sistem Ketatanegaraan Indonesia" ini menggunakan metode kualitatif dengan teknik deskriptif analitis. Sedangkan teknik pengumpulan datanya dilakukan melalui studi pustaka dengan penelusuran terhadap sumber-sumber tertulis. Sumber pokok adalah buku-buku literatur, tulisan ilmiah serta laporan yang memuat konten hasil penelitian. Artikel ini menfokuskan pada melihat bagaimana fenomena kotak kosong dalam pelaksanaan Pilkada Serentak sejak tahun 2015 hingga 2018.

\section{Pembahasan}

Putusan Mahkamah Konstitusi Nomor 100/PUU-XIII/2015 pada awalnya lahir sebagai upaya untuk menghindari 
gugurnya Hak Konstitusi rakyat yaitu hak untuk memilih dan dipilih. Bagi kandidat kepala daerah yang tidak mempunyai rival, maka penundaan yang dilakukan oleh KPU berimplikasi hilangnya hak dia untuk dipilih sebagai Kepala Daerah, disisi lain bagi rakyat, penundaan berarti penghilangan Hak bagi rakyat untuk memilih kepala daerahnya.

Menurut Austin Ranney (dalam Rusli Karim; 2016) ada tiga kriteria pokok sebuah pemilu yang demokratis meliputi : (1). Adanya hak pilih umum (aktif dan pasif), maksudnya adalah dalam pemilu eksekutif maupun legislatif setiap warga negara mempunyai kesempatan yang sama dalam ruang publik untuk memilih dan dipilih. Hak pilih aktif adalah hak warga negara yang sudah memenuhi syarat untuk memilih wakilnya di DPR, DPD, DPRD, Presiden-Wapres, dan Kepala Daerah-Wakil Kepala Daerah yaitu berusia 17 tahun atau sudah/ pernah menikah, tidak terganggu ingatannya, tidak dicabut hak pilihnya, tidak sedang menjalani hukum pidana penjara, terdaftar dalam Daftar Pemilih Tetap (DPT). Adapun yang dimaksud hak pilih pasif adalah hak warga negara yang sudah memenuhi syarat untuk dipilih menjadi anggota DPR dan DPRD. (2). Kesetaraan bobot suara, maksudnya adalah adanya keharusan jaminan bahwa suara tiap-tiap pemilih diberi bobot yang sama dalam pemilu tersebut. Semua pemilih memiliki bobot persentase perorangnya sama tanpa memikirkan jabatan dan kedudukan. (3). Tersedianya pilihan kandidat dari latarbelakang ideologis yang berbeda. Maksud dari kriteria ini adalah tersedianya pemilihan

yang nyata dan kelihatan perbedaannya dengan pilihan-pilihan yang lain dimana hakikatnya memang mengharuskan pilihan lebih dari satu, kemudian pilihan tersebut bisa sangat sederhana seperti perbedaan antara dua orang atau lebih calon atau perbedaan yang lebih rumit antara dua atau lebih garis politik/program kerja yang berlainan sampai ke perbedaan antara dua atau lebih ideologi (Syafhendry,2017:84).

Keberadaan calon tunggal tentu saja tidak sejalan dengan konsep yang disampaikan oleh Austin Ramsey, disebabkan fenomena tersebut membuat masyarakat tidak mempunyai alternatif dalam menentukan hak pilihnya. Disisi lain, masyarakat juga dipaksa untuk memilih satu kandidat yang (mungkin) tidak sejalan dengan ideologi dan keinginan mereka.

Kotak kosong adalah fenomena puncak gunung es yang selama ini terjadi di lembaga partai politik, pragmatisme politik, kegagalan kaderisasi serta miskinnya ideologi membuat partai politik tak lebih sebagai kendaraan semata. Partai Politik tidak mempunyai identitas, ideologi dan kualitas untuk menjalankan fungsinya sebagai partai politik.

Dalam Pilkada serentak, merujuk pada PKPU, apabila hanya dilakukan oleh kandidat perseorangan maka calon perseorangan tersebut akan disandingkan dengan kotak kosong. Secara psikologis, sosiologis dan antropologis, pertarungan antara kandidat yang diusung oleh hampir atau seluruh partai politik tidak akan mungkin kalah ketika hanya dihadapkan melawan kotak kosong, yang manatidak mempunyai partai pengusung, kandidat yang ditawarkan, serta nihil visi dan misi, bahkan justru menawarkan penundaan pemilihan kepala daerah pada pemilu serentak periode selanjutnya. Dalam 
tahap ini yang kemungkinan diuntungkan hanya Pejabat Sementara yang ditunjuk sebagai kepala daerah dan sejumlah orang yang berhasrat menjadi kepala daerah namun terbentur persyaratan KPU seperti batasan umur atau jumlah dukungan yang kurang memadai apabila hendak menggunakan jalur independen. Oleh karena itu sebenarnya Putusan MK sangat menguntugkan bagi calon tunggal yang berkontestasi dalam Pilkada, karena selain hanya menghadapi lawan yang tidak terlihat, kemenangan kotak kosong secara sosiologis akan merugikan rakyat, mereka untuk sementara waktu akan dipimpin oleh pelaksana tugas, yang secara hukum dibatasi kewenangannya dan menimbulkan potensi lahirnya kembali bentuk pemerintahan yang tersentralisasi kembali ke pusat.

Akan tetapi, teori tetaplah hanya teori. Pada periode Pemilu serentak tahap I, kotak kosong memang hanya menjadi penghias kontestasi, namun dalam pemilu serentak tahap kedua kotak kosong secara megejutkan mampu menjadi protagonis disejumlah daerah.

\subsection{Pemilu Serentak Tahun 2015}

Fenomena calon tunggal pertama kali muncul pada tahun 2015. Pada waktu itu, terdapat sejumlah daerah yang hampir gagal menyeleggarakan Pilkada, disebabkan karena tidak adanya dasar hukum yang kuat terkait legalitascalon tunggal. Kemudian, Putusan MK berhasil mengurai persoalan tersebut. Pada Pilkada serentak Periode I daerah-daerah yang menyelenggarakan Pilkada serentak dengan calon tunggal adalah Kabupaten Blitar, Kabupaten Tasikmalaya, dan Kabupaten Timor Tengah Utara di Provinsi Nusa Tenggara Timur (NTT).
Tabel 2.1. Hasil Pilkada Serentak dengan Calon Tunggal Tahun 2015

\begin{tabular}{|c|l|c|c|}
\hline No & \multicolumn{1}{|c|}{ Daerah } & Kandidat & $\begin{array}{c}\text { Kotak } \\
\text { Kosong }\end{array}$ \\
\hline 1 & Kota Blitar & $84,9 \%$ & $15,1 \%$ \\
\hline 2 & $\begin{array}{l}\text { Kabupaten } \\
\text { Timor } \\
\text { Tengah Utara }\end{array}$ & $79,89 \%$ & $21,11 \%$ \\
\hline 3 & $\begin{array}{l}\text { Kabupaten } \\
\text { Tasikmalaya }\end{array}$ & $67,35 \%$ & $32,65 \%$ \\
\hline
\end{tabular}

Sumber: diolah oleh Peneliti dari berbagai sumber

Terlihat dalam tabel diatas, pelaksanaan 3 (tiga) Pilkada serentak dimenangkan oleh calon tunggal dengan selisih suara yang besar. Pada titik ini untuk sementara bisa kita simpulkan bahwa argumentasi yang menyatakan bahwa masyarakat memang menginginkan hanya satu calon yang berkompetisi dalam Pilkada bisa dibenarkan dengan hasil Pilkada serentak tahun 2015 ini. Konsekuensi lahirnya Pelaksana Tugas untuk waktu yang lama belum terjadi pada Pilkada serentak Tahap I.

\subsection{Pilkada Serentak Tahun 2017}

Pilkada serentak tahun 2017 merupakan pelaksanaan Pilkada serentak yang memberi peluang calon tunggal untuk ikut berpartisipasi. Pada tahun 2017 jumlah calon tunggal yang berkontestasi bukannya malah berkurang, namun justru semakin bertambah banyak. Tercatat ada 9 (sembilan) daerah yang Pilkada nya hanya terdapat calon tunggal. 
Tabel 2.2. Hasil Pilkada Serentak dengan Calon Tunggal Tahun 2017

\begin{tabular}{|c|l|c|c|}
\hline No & \multicolumn{1}{|c|}{ Daerah } & Kandidat & $\begin{array}{c}\text { Kotak } \\
\text { Kosong }\end{array}$ \\
\hline 1 & $\begin{array}{l}\text { Kota Tebing } \\
\text { Tinggi }\end{array}$ & $71,32 \%$ & $28,68 \%$ \\
\hline 2 & $\begin{array}{l}\text { Kabupaten } \\
\text { Tulang } \\
\text { Bawang }\end{array}$ & $97,49 \% \%$ & $2,51 \%$ \\
\hline 3 & $\begin{array}{l}\text { Kabupaten } \\
\text { Pati }\end{array}$ & $72,94 \%$ & $27,06 \%$ \\
\hline 4 & $\begin{array}{l}\text { Kabupaten } \\
\text { Landak }\end{array}$ & $96,62 \%$ & $3,38 \%$ \\
\hline 5 & $\begin{array}{l}\text { Kabupaten } \\
\text { Maluku } \\
\text { Tengah }\end{array}$ & $70,79 \%$ & $29,21 \%$ \\
\hline 6 & Kota Jayapura & $84,34 \%$ & $15,66 \%$ \\
\hline 7 & $\begin{array}{l}\text { Kabupaten } \\
\text { Tambrauw }\end{array}$ & $85,98 \%$ & $14,02 \%$ \\
\hline 8 & $\begin{array}{l}\text { Kabupaten } \\
\text { Sorong }\end{array}$ & $78,09 \%$ & $21,91 \%$ \\
\hline 9 & $\begin{array}{l}\text { Kabupaten } \\
\text { Buton }\end{array}$ & $55,08 \%$ & $44,92 \%$ \\
\hline
\end{tabular}

Sumber: diolah oleh Peneliti dari berbagai sumber

Pada Pilkada serentak tahun 2017, meskipun semakin menegaskan bahwa keberadaan calon tunggal adalah keinginan sebagian besar rakyat, namun di Kabupaten Buton calon tunggal benarbenar menghadapi pertarungan yang berat dengan kotak kosong. Selisih suara antara kotak kosong dan calon tunggal tidak lebih dari $11 \%$. Hal ini menunjukkan bahwa meskipun secara hasil calon tunggal memenangkan semua kontestasi Pilkada di sejumlah daerah, akan tetapi secara kualitas hal ini membuktikan bahwa sebenarnya di beberapa daerah caon tunggal tidak cukup mendapat dukungan suara dari rakyat.

\subsection{Pilkada Serentak 2018}

Pada Pilkada serentak tahun 2018, fenomena keberadaan calon tunggal melesat pesat menjadi 16 (enam belas) calon di sejumlah daerah. Daerah-daerah tersebut adalah

Tabel 2.3. Hasil Pilkada Serentak dengan Calon Tunggal Tahun 2017

\begin{tabular}{|c|l|c|c|}
\hline No & \multicolumn{1}{|c|}{ Daerah } & Kandidat & $\begin{array}{c}\text { Kotak } \\
\text { Kosong }\end{array}$ \\
\hline 1 & $\begin{array}{l}\text { Kabupaten } \\
\text { Deli Serdang }\end{array}$ & $82,95 \%$ & $17,14 \%$ \\
\hline 2 & $\begin{array}{l}\text { Kabupaten } \\
\text { Padang } \\
\text { Lawas Utara }\end{array}$ & $80,12 \%$ & $19,88 \%$ \\
\hline 3 & $\begin{array}{l}\text { Kota } \\
\text { Prabumulih }\end{array}$ & $79,27 \%$ & $20,73 \%$ \\
\hline 4 & $\begin{array}{l}\text { Kabupaten } \\
\text { Pasuruan }\end{array}$ & $81,44 \%$ & $18,56 \%$ \\
\hline 5 & $\begin{array}{l}\text { Kabupaten } \\
\text { Lebak }\end{array}$ & $76,96 \%$ & $23,04 \%$ \\
\hline 6 & $\begin{array}{l}\text { Kabupaten } \\
\text { Tangerang }\end{array}$ & $83,72 \%$ & $16,28 \%$ \\
\hline 7 & $\begin{array}{l}\text { Kota } \\
\text { Tangerang }\end{array}$ & $85,80 \%$ & $14,20 \%$ \\
\hline 8 & $\begin{array}{l}\text { Kabupaten } \\
\text { Tapin }\end{array}$ & $80,87 \%$ & $19,13 \%$ \\
\hline 9 & $\begin{array}{l}\text { Kabupaten } \\
\text { Minahasa } \\
\text { Tenggara }\end{array}$ & $67,26 \%$ & $32,74 \%$ \\
\hline 10 & $\begin{array}{l}\text { Kabupaten } \\
\text { Enrekkang }\end{array}$ \\
\hline 11 & $\begin{array}{l}\text { Kota } \\
\text { Makassar }\end{array}$ & $\begin{array}{l}\text { Kabupaten } \\
\text { Mamasa }\end{array}$ \\
\hline 13 & $\begin{array}{l}\text { Kabupaten } \\
\text { Mamberamo } \\
\text { Tengah }\end{array}$ & $\begin{array}{l}\text { Kabupaten } \\
\text { Puncak }\end{array}$ & $86,73 \%$ \\
\hline $12,23 \%$ \\
\hline
\end{tabular}




\begin{tabular}{|c|l|c|c|}
\hline 15 & $\begin{array}{l}\text { Kabupaten } \\
\text { Jayawijaya }\end{array}$ & $99,13 \%$ & $0,87 \%$ \\
\hline 16 & $\begin{array}{l}\text { Kabupaten } \\
\text { Bone }\end{array}$ & $63,05 \%$ & $36,95 \%$ \\
\hline
\end{tabular}

Sumber: diolah oleh Peneliti dari berbagai sumber

Apabila merujuk pada tabel di atas terlihat bahwa hasil Pilkada yang mempertemukan calon tunggal melawan kotak kosong hasilnya semakin lama semakin bervariasi. Di beberapa daerah sejumlah kandidat terlihat begitu menguasai dan mendominasi hasil Pilkada, bahkan di Kabupaten Jayawijaya calon tunggal berhasil memenangkan Pilkada dengan prosentase 99\%. Hal sama juga terjadi di Kabupaten Puncak, yang mana calon tunggal berhasil memperoleh suara diatas $90 \%$.

Akan tetapi, hasil yang mengejutkan justru terjadi di Kota Makassar. Di ibukota Provinsi Sulawesi Selatan ini, Kotak Kosong berhasil mengalahkan calon tunggal Pasangan Munafri Arifuddin-Andi Rahmatika Dewi (Appi-Cicu). Kekalahan calon tunggal sekaligus kemenangan kotak kosong ini merupakan kejadian pertama yang terjadi di Pilkada serentak di Indonesia, lantas bagaimanakah dampak tumbangnya calon tunggal ini dilihat dalam sistem hukum ketatanegaraan Indonesia?.

\subsection{Fenomena Kotak Kosong dalam Sistem Hukum Ketatanegaraan}

Ketika berbicara mengenai sistem hukum ketatanegaraan ada beberapa hal yang terdampak dari proses demokrasi yang menghadirkan kontestasi calon tunggal dan kotak kosong. Persoalan itu terkait jabatan kepala daerah hingga potensi lahirnya kembali sistem sentralisasi ketika kotak kosong memenangkan proses demokrasi. Secara singkat, persoalan itu bisa di inventarisir ke dalam tiga hal, yaitu:

1) Kosongnya Jabatan Kepala Daerah Definitif di suatu daerah Salah satu dampak kekalahan calon tunggal serta kemenangan kotak kosong adalah ketiadaan Pejabat Kepala Daerah definitif di daerah tersebut. Ketentuan ini mengacu kepada Peraturan Peraturan KPU Nomor 13 Tahun 2018 Pasal 25 ayat (3), yang mana disebutkan bahwa:

(3) Dalam hal terjadi penetapan penyelenggaraan Pemilihan serentak periode berikutnya sebagamana dimaksud pada ayat (1), KPU Provinsi/KIP Aceh atau KPU/KIP Kabupaten/Kota melalui KPU berkoordinasi dengan kementerian yang membidangi urusan dalam negeri untuk penugasan penjabat Gubernur dan Wakil Gubernur, penjabat Bupati dan Wakil Bupati, atau penjabat Wali Kota dan Wakil Wali Kota.

Penugasan yang dimaksud dalam ketentuan pasal ini tentu saja bukan pejabat definitif yang dipilih melalui proses demokrasi, melainkan pejabat pelaksana tugas yang di angkat oleh Menteri dalam Negeri untuk mengisi kekosongan sementara waktu.

Hanya saja persoalannya adalah, kekosongan yang terjadi dalam konteks ini bukanlah kekosongan yang sebentar atau semetara (temporary), melainkan kekosongan dalam jangka waktu yang cukup lama.Sebagai contoh adalah Pilkada Tahun 2015 dilaksanakan pada tanggal 9 Desember 2015, sementara 
itu pelaksanaan Pilkada selanjutnya dilakukan pada tanggal 15 Februari 2017 dan yang ketiga dilakukan pada tanggal 27 Juni 2018.

Tabel 2.4. Pelaksanaan Pilkada dan Selisih Waktu Kekosongan Jabatan

\begin{tabular}{|c|c|c|}
\hline Pilkada & Pelaksanaan & Selisih Waktu \\
\hline I & $\begin{array}{c}9 \text { Desember } \\
2015\end{array}$ & - \\
\hline II & $\begin{array}{c}15 \text { Februari } \\
2017\end{array}$ & $\begin{array}{c}\text { 1 Tahun 2 } \\
\text { Bulan 6 Hari }\end{array}$ \\
\hline III & 27 Juni 2018 & $\begin{array}{c}\text { 1 Tahun 4 } \\
\text { Bulan 12 Hari }\end{array}$ \\
\hline
\end{tabular}

Sumber: diolah oleh Peneliti dari berbagai sumber

Apabila kita melihat tabel diatas terlihat bahwa jarak antara Pilkada serentak I dan II cukup jauh dan ketiadaan pejabat definitif bisa memunculkan persoalan baru dalam sistem ketatanegaraan Indonesia.

Dalam kajian hukum administrasi negara, pejabat definitif mempunyai perbedaan yang signifikan dengan pejabat pelaksana tugas (Plt) dan pelaksana harian (Plh). Apabila kita mengacu pada Pasal 6 ayat (1) dan (2) Undang-Undang Nomor 30 Tahun 2014 tentang Administrasi Pemerintahan, Perbedaan mendasar antara Pelaksana Harian (interim) dengan Pelaksana Tugas (acting) adalah Pelaksana Harian melaksanakan tugas rutin dari pejabat definitif yang berhalangan sementara, sedangkan Pelaksana Tugas melaksanakan tugas rutin dari pejabat definitif yang berhalangan tetap. Perbedaan definisi itu juga ditegaskan secara lebih jelas oleh Chapman et al. (1988), the line separates an interim, who assumes "regular responsibilities during a specified period", and the acting, who holds "less-than-regular leadership on an interim basis". The difference relates to whether during the duration one actually acts "as" the leader (the interim), or "like" a leader (the acting). (Newcombe, 2013:190)

Sementara itu dalam Pasal 14 ayat (2) Pelaksana Harian ("PIh") adalah pejabat yang melaksanakan tugas rutin dari pejabat definitif yang berhalangan sementara, sedangkan Pelaksana Tugas ("Plt") adalah pejabat yang melaksanakan tugas rutin dari pejabat definitif yang berhalangan tetap.

Plh dan Plt merupakan pejabat yang melaksanakan tugas rutin berupa mandat. Badan dan/atau Pejabat Pemerintahan memperoleh mandat apabila:

- ditugaskan oleh Badan dan/atau Pemerintahan di atasnya, dan

- merupakan pelaksanaan tugas rutin.

Plh ditunjuk oleh Pejabat Pemerintahan di atasnya apabila terdapat pejabat yang tidak dapat melaksanakan tugas paling kurang 7 (tujuh) hari kerja untuk tetap menjamin kelancaran pelaksanaan tugas.Jadi perbedaan mendasar antara Plh dengan Plt adalah Pelaksana Harian melaksanakan tugas rutin dari pejabat definitif yang berhalangan sementara, sedangkan Pelaksana Tugas melaksanakan tugas rutin dari pejabat definitif yang berhalangan tetap.

Karena Plh atau PIt merupakan pejabat yang melaksanakan tugas rutin yang merupakan salah satu bentuk mandat, apabila merujuk pada Surat Kepala Badan Kepegawaian Negara Nomor K.26-30/V.20-3/99 Tahun 2016 tentang Kewenangan Pelaksana Harian dan Pelaksana Tugas dalam Aspek Kepegawaian, maka Plh atau Plt tidak berwenang mengambil keputusan dan/ 
atau tindakan yang bersifat strategis yang berdampak pada perubahan status hukum pada aspek organisasi, kepegawaian, dan alokasi anggaran.

Sementara itu yang dimaksud dengan "Keputusan dan/atau Tindakan yang bersifat strategis" artinya Keputusan dan/ atau Tindakan yang memiliki dampak besar seperti penetapan perubahan rencana strategis dan rencana kerja pemerintah. "Perubahan status hukum organisasi" artinya menetapkan perubahan struktur organisasi. "Perubahan status hukum kepegawaian" artinya melakukan pengangkatan, pemindahan, dan pemberhentian pegawai. "Perubahan alokasi anggaran" artinya Plh atau Plt tidak boleh melakukan perubahan anggaran yang sudah ditetapkan alokasinya

Adapun kewenangan Plh dan Plt merujuk pada Surat Kepala Badan Kepegawaian Negara Nomor K.2630/V.20-3/99 Tahun 2016 tentang Kewenangan Pelaksana Harian dan Pelaksana Tugas dalam Aspek Kepegawaian antara lain meliputi:

- menetapkan sasaran kerja pegawai dan penilaian prestasi kerja;

- menetapkan kenaikan gaji berkala;

- menetapkan cuti selain Cuti di Luar Tanggungan Negara (CLTN);

- menetapkan surat penugasan pegawai;

- menyampaikan usul mutasi kepegawaian kecuali perpindahan antar instansi; dan

- memberikan izin belajar, izin mengikuti seleksi jabatan pimpinan tinggi/administrasi, dan izin tidak masuk kerja

Jadi, dalam menjalankan tugasnya Plh atau Plt tidak berwenang mengambil keputusan dan/atau tindakan yang bersifat strategis yang berdampak pada perubahan status hukum pada aspek organisasi, kepegawaian, dan alokasi anggaran.

Kondisi ini tentu saja tidak menguntungkan bagi daerah yang mengalami kekosongan kekuasaan dalam periode yang lama. Untuk mengatasi persoalan ini, Kementerian Dalam Negeri kemudian membuat Peraturan Menteri Dalam Negeri Republik Indonesia Nomor 1 Tahun 2018 Tentang Perubahan Atas Peraturan Menteri Dalam Negeri Nomor 74 Tahun 2016 Tentang Cuti Di Luar Tanggungan Negara Bagi Gubernur Dan Wakil Gubernur, Bupati Dan Wakil Bupati, Serta Wali Kota Dan Wakil Wali Kota yang di dalam ketentuannya diberikan kewenangan sebagaimana Pejabat definitif, seperti:

\section{Pasal 9}

(1) Pjs gubernur, Pjs bupati, dan Pjs wali kota mempunyai tugas dan wewenang:

a. memimpin pelaksanaan urusan pemerintahan yang menjadi kewenangan daerah berdasarkan ketentuan peraturan perundangundangan dan kebijakan yang ditetapkan bersama Dewan Perwakilan Rakyat Daerah;

b. memelihara ketentraman dan ketertiban masyarakat;

c. memfasilitasi penyelenggaraan pemilihan gubernur dan wakil gubernur, bupati dan wakil bupati wali kota dan wakil wali kota yang definitif serta menjaga netralitas Pegawai Negeri Sipil; dan

d. melakukan pembahasan rancangan Peraturan Daerah dan dapat menandatangani Peraturan Daerah setelah mendapat persetujuan 
tertulis dari Menteri Dalam Negeri; dan

e. melakukan pengisian pejabat berdasarkan ketentuan peraturan perundang-undangan setelah mendapat persetujuan tertulis dari Menteri Dalam Negeri.

(2) Dalam melaksanakan tugas dan wewenang sebagaimana dimaksud pada ayat (1), Pjs gubernur, Pjs bupati, dan Pjs wali kota bertanggung jawab dan wajib menyampaikan laporan pelaksanaan tugas kepada Menteri.

Peraturan Menteri Dalam Negeri ini secara yuridis memberikan legitimasi bagi Pjs untuk menjalankan roda pemerintahan sebagaimana Pejabat definitif. Meskipun Peraturan Menteri Dalam Negeri tersebut menjadi solusi atas sejumlah persoalan terkait ketiadaan Pajabat definitif, namun secara aspek yuridis peraturan tersebut melanggar ketentuan yang tedapat dalam Undang-Undang Nomor 30 Tahun 2014 tentang Administrasi Pemerintahan yang memposisikan Pejabat definitif dan Plt serta Plh mempunyai perbedaan terkait kewenangan. Mengacu pada asas hukum lex superiori derogat lex inferiori harusnya Permendagri No.1 Tahun 2018 tidak bisa diberlakukan, karena bertentangan dengan hierarki peraturan di atasnya. Situasi iniberpotensi melahirkan gugatan judicial review ke Mahkamah Agung terhadap Peraturan Menteri Dalam Negeri No.1 Tahun 2018 yang secara aturan perundang-undangan cacat hukum. Dan apabila pada akhirnya nanti dikabulkan, maka potensi munculnya kekosongan kekuasaan jabatan Kepala Daerah akan kembali terjadi.

Dalam konteks inilah, Penulis melihat bahwa fenomena kotak kosong dalam Pilkada ini akan menciptakan persoalan baru dalam sistem ketatanegaraan Indonesia, antara lain:

1) Potensi kembalinya sistem pemerintahan sentralisasi

Salah satu efek yang ditimbulkan dari kemenangan kotak kosong sebagaimana penjelasan diatas yaitu potensi ketidakhadiran Kepala Daerah definitif di daerah tersebut. Apabila mengacu pada Peraturan KPU Nomor 13 Tahun 2018 yang merupakan acuan teknis dari UndangUndang Pemilihan Kepala Daerah, jabatan tersebut nantinya akan diisi oleh Pejabat sementara yang mana kewenangan pengisiannya diberikan kepada Menteri Dalam Negeri, yang merupakan Pejabat Pemerintahan Pusat yang dipilih secara langsung oleh Presiden.

Padahal sebagai ekses dari amanden konstitusi Pasal 18, Pemerintah Daerah diberikan kewenangan untuk mengelola daerahnya sendiri. Sejak saat itu kewenangan Pemerintah Pusat hanya terbatas pada kewenangan Politik Luar Negeri, Pertahanan dan Keamanan, Moneter, Fiskal, Yustisi dan Agama. Diluar kewenangan tersebut, semuanya menjadi kewenangan Pemerintah Daerah.

\section{Pasal 18}

(2) Pemerintah daerah provinsi, daerah Kabupaten, dan Kota mengatur dan mengurus sendiri urusan pemerintahan menurut asas otonomi dan tugas pembantuan.

(5) Pemerintahan daerah menjalankan otonomi seluas-luasnya, kecuali urusan pemerintahan yang oleh undang-undang ditentukan sebagai urusan Pemerintahan Pusat.

Berdasarkan Pasal 18 ayat (2) 
dan (5) terlihat dengan sangat jelas bahwa Pemerintah Daerah mempunyai wewenang untuk mengatur dan mengurus sendiri urusan pemerintahan menurut asas otonomi dan tugas pembantuan. Selain itu ketentuan ini juga ditegaskan pada ketentuan ayat (5) yang menyatakan bahwa pemerintahan daerah menjalankan otonomi seluas-luasnya kecuali urusan pemerintahan yang oleh undang-undang ditentukan sebagai urusan Pemerintahan Pusat.

Apabila kita beranda-andai apabila kontestasi Pilkada menghadirkan calon tunggal menghadapi kotak kosong, dan kotak kosong memenangkan kontestasi, maka akan terjadi kekosongan kekuasaan dalam jangka waktu yang cukup panjang. Merujuk pada tabel 4, terlihat bahwa ada kekosongan kekuasaan yang cukup panjang bahkan hingga hampir dua tahun. Akan tetapi perpanjangan tersebut terancam berpotensi jauh lebih lama apabila kita sudah secara resmi mengadakan Pilkada serentak pada tahun 2027, yang mana apabila aturan ini masih berlaku, Pjs bisa saja memerintah suatu daerah selama 5 (lima) tahun. Dasar hukumnya adalah ketentuan pada Undang-Undang Pilkada dimana Pjs Kepala Daerah dipilih oleh Menteri Dalam Negeri sampai penyelenggaraan Pilkada berikutnya.

Pasal ini secara sistem ketatanegaraan telah melanggar konstitusi pada Pasal 18, dimana Gubernur, Bupati, dan Walikota masing-masing sebagai kepala pemerintah daerah provinsi, kabupaten dan kota dipilih secara demokratis, bukan oleh Pemerintah Pusat.

Pemilihan Pjs yang mempunyai kewenangan setara dengan Menteri Dalam Negeri secara perlahan-lahan akan menciptakan sentralisasi dalam wajah baru. Kenapa hal itu terjadi?, karena Plt baik di tingkat Provinsi maupun Kabupaten/Kota merupakan Pejabat Kementerian Dalam Negeri yang ditunjuk secara langsung oleh Menteri Dalam Negeri, dan sebelum mengambil kebijakan yang bersifat strategis, pejabat tersebut harus melakukan konsultasi terlebih dahulu kepada Menteri Dalam Negeri. Secara tidak langsung, otonomi daerah telah bergerak mundur kembali ke bentuk sentralisasi sebagaimana di era orde baru. Saat ini hanya Kota Makassar yang menjadi saksi sejarah kemenangan kotak kosong dalam kontestasi Pilkada, namun untuk kedepannya bisa saja hal ini terjadi di semua daerah, dan itu berimplikasi semua Kepala Daerah nantinya akan dipimpin oleh Pjs yang dipilih oleh Pemerintah Pusat. Dan jika kondisi itu benar-benar akan terjadi, maka hal tersebut merupakan kemunduran bagi demokrasi kita.

2) Hilangnya hak masyarakat untuk dipimpin oleh Pemimpin pilihannya

Salah satu pertimbangan hukum dari Putusan Mahkamah Konstitusi Nomor: 100/PUU/2015 adalah hak rakyat, baik hak untuk dipilih maupun hak untuk memilih tidak boleh dikesampingkan atau diabaikan, lebih-lebih ditiadakan. Akan tetapi pernahkan kemudian rakyat memilih untuk dipimpin oleh Pjs yang ditunjuk oleh Gubernur?

Yang dimaknai dengan demokrasi oleh Abraham Lincoln adalah, 'government of the people, by the people and for the people'(Silveira dan Heinrich,2017:1650). Ketika tidak ada alternatif calon atau hanya terdapat calon tunggal, memang rakyat diberikan pilhan yaitu antara memilih calon tunggal atau kotak 
kosong. Akan tetapi ketika kotak kosong memenangkan kontestasi, kewenangan untuk mengangkat Pjs mutlak menjadi kewenangan Pemerintah Pusat.

Berkaca pada teori dasar tentang demokrasi, menurut Schumpter demokrasi adalah as a procedure for choosing leaders through competitive elections (Kokkinidis,2012:236). Hal ini juga disepakati oleh Dolephet (2016:470) yang menyebut bahwa terdapat lima indikator demokrasi, Renske melihat bahwa demokrasi bisa dilihat mulai dari skor tertinggi sampai dengan skor terendah,

Democracy is measured byfive indicators in total. Threeindicators focus on structural characteristics by which chief executivesare recruited. (1) The extent to which a country has institutionalizedprocedures for transferring executive power, so this indicator focuses on modes by which chief executives are selected. Countries inwhich'chief executives are determined by hereditary succession or incompetitive elections'get the highest score (Marshall et al. 2013: 201)for this indicator, while countries in which'changes in chief executiveoccur through forceful seizures of power'get the lowest score on thedemocracy scale. (2) The competitiveness of executive selection, so thisindicator refers to the'extent that prevailing modes ofadvancement give subordinates equal opportunities to become superordinates'(Gurr 1974: 1483). Countries in which'chief executives aretypically chosen in or through competitive elections matching two ormore major parties or candidates'get the highest score (Marshall et al.2013: 212) for this indicator, while countries get the lowest score whentheir chief executives are determined by hereditary succession orduring rigged, unopposed elections.

Menurut Renske suatu daerah mempunyai skor demokrasi terendah apabila pemimpinnya ditentukan berdasarkan keturunan, pemilu yang curang ataupun pemilihan yang tidak ada lawannya. Dalam konteks ini, calon tunggal menghadapi kotak kosong adalah titik terendah demokrasi, karena selain calon tunggal tersebut tidak terdapat lawan, kekalahan calon tunggal juga membuka potensi terpilihnya pemimpin yang tidak dikehendakisecara langsung oleh rakyat, kondisi ini ibarat membeli kucing di dalam karung, meskipun pada dasarnya rakyat mengetahui bahwa di dalamnya ada kucing namun rakyat tidak mengetahui bagaimana perilakunya, jenis kelaminnya hingga warna kulitnya, walaupun kondisi itu merupakan pilihan rakyat dan rakyat sudah tahu serta paham terhadap konsekuensi tersebut.

\section{Simpulan}

Putusan Mahkamah Konstitusi adalah Putusan pertama dan terakhir, bersifat final, mengikat sertaerga omnes (berlaku untuk semua). Meskipun pada akhirnya beberapa Putusan menjadi persoalan bagi sistem ketatanegaraan Indonesia, dalam konteks ini adalah Putusan yang memperbolehkan calon tunggal menghadapi kota kosong. Kekalahan kotak kosong bisa jadi memang keinginan masyarakat yang menghendaki kandidat tersebut memenangkan kontestasi, namun bisa jadi sebaliknya, yaitu pragmatisme Partai Politik yang mana suaranya bisa dikooptasi demi sekoper uang. 
Sejak Pilkada serentak dilakukan pada tahun 2015 hingga 2018, sejumlah daerah yang terdapat calon tunggal, kotak kosong kerapkali mengancam suara calon tunggal, bahkan pada tahun 2018 di Pilkada Kota Makassar, kotak kosong berhasil menumbangkan kandidat calon tunggal dengan selisih suara yang signifikan.

Secara ketatanegaraan, demokrasi Indonesia berjalan selangkah lebih mundur ke belakang dengan dibolehkannya calon tunggal berkontestasi dalam Pilkada, karena ketika calon tunggal memenangkan Pilkada calon tersebut menang dengan ketidakadaan calon alternatif, namun ketika kotak kosong menang maka untuk beberapa waktu kedepan daerah tersebut akan dipimpin oleh orang yang ditunjuk langsung oleh Pemerintah Pusat. Dan potensi untuk lahirnya kembali sistem sentralisasi sebagaimana yang terjadi pada orde baru bukan lagi sekedar mimpi di siang bolong.
Untuk mengatasi persoalan ini, sebenarnya bisa diatasi dengan dua cara yaitu pertama membangun pelembagaan partai politik secara ideal yaitu dengan menguatkan fungsi-fungsi partai politik sebagai sarana rekrutmen politik dan kaderisasi. Dengan berjalannya fungsi rekrutmen dan kaderisasi, maka kecil kemungkinan suatu partai politik tidak mengusung calon dalam Pilkada. Kedua adalah dbuatnya regulasi terkait ambang batas maksimum dukungan kepala daerah, seperti maksimal didukung oleh $60 \%$ kursi parlemen atau $50 \%$ suara suara dan jika partai tersebut tidak memberikan dukungannya maka ada sanksi administratif yaitu partai tersebut tidak bisa mengusung calon lagi untuk Pilkada berikutnya. 


\section{DAFTAR PUSTAKA}

Balkin, Jack M, (2016), Cultural Democracy And The First Amendment, North Western University Law Review, Vol. 110, No.5

Doorenspleet, Renske, (2015), Where Are the People? A Call for People-Centred Concepts and Measurementsof Democracy, Government and Opposition, Vol. 50, No. 3

Kokkinidis, George, (2012), In search of workplace democracy, International Journal of Sociology and Social Policy Vol. 32 No. 3/4

Newcombe, Pat A., (2013), Becoming director: an internal candidate's view, Library Management Vol. 34 No. 3

Silveira, Lina dan Horst-Alfred Heinrich, (2017), Drawing democracy: popular conceptions of democracy in Germany, Qual Quant, Vol 51

Syafhendry, (Juni 2017), Makna Pencoblosan Dalam Pemilihan Umum, Jurnal IImu Politik Dan Komunikasi Volume VII No. 1

Undang-Undang Nomor 30 Tahun 2014 tentang Administrasi Pemerintahan

Peraturan Komisi Pemilihan Umum Nomor 14 tahun 2015

Putusan Mahkamah Konstitusi Nomor 100/PUU-XIII/2015

84 Jurnal Adhyasta Pemilu 